\author{
Наталія Акімова \\ ДВНЗ «Переяслав-Хмельницький державний педагогічний \\ університет імені Григорія Сковороди», \\ natashashadow8@gmail.com
}

\title{
ПСИХОЛОГІЧНИЙ МЕХАНІЗМ РОЗУМІННЯ ТЕКСТУ
}

\begin{abstract}
Стаття присвячено обтрунтуванню психологічного механізму розуміння тексту на основі узагальнення трунтовних сучасних розробок з указаної тематики. Зазначено, щзо питання про механізм розуміння тексту ще не отримало вичерпної відповіді. Найчастіше для пояснення психологічного механізму розуміння тексту використовують теорію гіпотез, теорію спільності значення, гіпотезу біологічної $і$ функціональної схожості приписування значень, модель контекстуального семантичного обмеження слів, гіпотезу релевантності контексту, теорію дзеркальних нейронів та концепцію свідомого смислотворення. Проте використання методів узагальнення, аналізу та синтезу наукової літератури, елементів описового, корелятивного та концептуального аналізів дозволило висунути припущеення, щзо психологічним механізмом розуміння тексту є взаємодія сенсу та значення.

Науковий аналіз зазначених понять привів до виокремлення їх диференційних ознак та дав підстави узгодити репрезентовані міркування у наступну гіпотезу: в результаті розуміння у свідомості суб'єкта виникають певні організовані уявлення щзодо тексту - смисли, які згодом об'єктивуються у вторинний текст. Відтак психологічним механізмом розуміння є проиес розкладання значень тексту на їх семантичні компоненти та утворення на иій основі власних вторинних смислів. Критерієм відбору прийнятних смислів може виступати контекст, шзо підтримує одні смисли та відкидає інші на основі спільності попереднього смислового змісту (Р. Краус, Н. В. Ігнатенко, В. В. Жовтянська, Г. В. Лосик), або ширше - спільний досвід, ш⿻о формує такий спільний контекст (О. О. Залевська, М. Якобоні). Смисл виникає при зіткненні пропонованого текстом значення з наявними y свідомості рециипієнта смислами за потреби їх узгодження; значення - загальне, об'єктивне, закріплене за словом, смисл-індивідуальний, суб'єктивний, не закріплений, а лише асоційований, тому він, як правило, иириий за значення.
\end{abstract}

Ключові слова: розуміння, розуміння тексту, механізм розуміння, значення, сенс, смисл.

Вступ. Українська психологія все більше заглиблюється у коло суспільно важливих проблем, що мають широке застосування в сучасному світі, зокрема й у проблему розуміння тексту, якій присвячено низку грунтовних та безумовно актуальних праць Н. В. Чепелєвої, Н. М. Савелюк, Н. В. Харченко та ін. [18; 24; 25]. Зосереджуючись на різних видах текстів, вони вносять значний вклад у загальну теорії розуміння тексту, яка формується в Україні, набуваючи специфічного українського колориту, що відзначається взаємною узгодженістю та уважністю до деталей. Проте деякі аспекти цієї теорії поки що розроблені недостатньо та потребують окремих спеціалізованих досліджень. До таких питань належить і визначення узагальненого психологічного механізму розуміння тексту.

Аналіз досліджень. Питання про механізм розуміння тексту сьогодні ще лишається відкритим. У науковій літературі пропонується кілька концепцій на пояснення цього механізму:

- теорія гіпотез (Краус, 1988): декодування мовленнєвого повідомлення відбувається через послідовне висування та перевірку гіпотез реципієнтом. Цей процес спрямований на виявлення серед безлічі значень доречних i, як правило, є згорнутим та неусвідомлюваним. Провідним фактором відбору при цьому виступає контекст [8];

- теорія спільності значення (Леонтьєв, 1996): у двох сенсах осіб, що спілкуються, є спільна частина - значення цього слова, - і тільки завдяки наявності такої спільної частини ми розуміємо один одного [10, с. 19];

- гіпотеза біологічної і функціональної схожості приписування значень (Залевська, 1999): значення в мозку різних людей пов'язані не тому, що вони є копіями деякого зовнішнього значення, а внаслідок того, що мозок у різних людей має біологічну і функціональну схожість щодо діяльності приписування значень ... навіть «найпростіші» значення, що використовуються нами в повсякденному житті, зовсім не $є$ «простими»: за ними стоять складні 
когнітивні операції, які не можуть бути безпосередньо передані мовними формами. Звідси випливає, що мова не $\epsilon$ «кодом» для таких операцій, вона тільки дає «ключі» для когнітивного конструювання; успішність користування такими ключами забезпечується ситуацією i контекстом. У ході спілкування нам тільки здається, що значення прямо міститься в мові. При оволодінні мовою діти засвоюють не абстрактну мовну систему, а повну систему когнітивного картування 3 усіма іiі перетинами і конфігураціями, супроводжувану засобами мовної маніфестації. Процеси, які відбуваються при функціонуванні значення, і в тому числі абстрагування, концептуальний перетин, категоризація і т. д. відбуваються з опорою на деякі приклади належності до того чи іншого класу об'єктів, прототипів, еталонів, на їх ознаки i ознаки ознак, на схожість і відмінності між ідентифікованими елементами мовного або енциклопедичного знання [6, с. 130-133];

- модель контекстуального семантичного обмеження слів (Ігнатенко, 2003): слова взаємно обмежують одне одного, внаслідок чого предметне значення слова змінюється залежно від його поєднання з іншими словами [7];

- гіпотеза релевантності контексту (Жовтянська, 2009): необхідним критерієм завжди є наявність загального смислу. I це цілком зрозуміло, тому що контекст завжди пов'язаний із суб'єктивною інтерпретацією, а значить суб'єктивною осмисленістю ситуації [5];

- теорія дзеркальних нейронів (Якобоні, 2011): дзеркальні нейрони кори головного мозку допомагають розуміти прочитане, внутрішньо симулюючи дію, про яку ми щойно прочитали, нібито ми власноруч зробили цю дію [27, с.115];

- свідоме смислотворення (Лосик, Фрідланд, Лебєдєв, Вартанов, 2016): сенс повідомленням надає свідомість індивіда. Вона $є$ генератором сенсу власного повідомлення і детектором сенсу отримуваного повідомлення [11, с. 268].

Мета статті та методи. Метою цієї статті $є$ окреслення узагальненого психологічного механізму розуміння тексту. Для цього використовується низка теоретичних методів, зокрема узагальнення, аналіз та синтез, описовий (прийоми логіко-психологічних й опозиційних інтерпретацій, словникової дефініції, компонентного аналізу та ін.), корелятивний та концептуальний аналізи.

\section{Виклад основного матеріалу та обгрунтування отриманих результатів.}

Більшість актуальних наукових теорій розуміння тексту сконцентровано навколо значення i сенсу, взаємодія яких, ймовірно, i $\epsilon$ механізмом розуміння. За свідченням Д. О. Леонтьєва, у російській і німецькій мовах у більшості випадків ці слова розглядаються як синоніми, а в англійській і французькій мовах переважно використовується тільки одне зі слів (англійське Meaning, а не sense і французьке Sens, а не Signification) [9, с. 8]. У російськомовній літературі плутанина доходить до того, що деякі автори розглядають смисли як окремий випадок значень, тоді як інші - значення як окремий випадок смислів [3; 22]. У психології теорія значень і сенсів вдосконалювалася в межах різних шкіл:

1. Згідно з необіхевіористською концепцією значення визначається як асоційована зі стимулом «репрезентативна реакція». Ця реакція сама в поведінці не проявляється, вона лише репрезентує суб'єкту готовність до реальної реакції. Тут психологічна структура значення розглядається лише у вузькому аспекті - 3 боку поведінкового (прагматичного) або конотативного значення. Знакові заступники реальних об'єктів (слова) отримують конотативне значення в результаті утворення системи умовних зв'язків між реальним стимулом і реальною реакцією, 3 одного боку, і стимульним (знаковим) заміщенням та «репрезентативною реакцією», з іншого. Як емпіричний аргумент на користь своєї умовнорефлекторної теорії значення Ч. Осгуд наводить відомий феномен «семантичного насичення»: при багаторазовому пред'явленні слова його сенс втрачається, подібно до того, як згасає умовний зв'язок без підкріплення [2, с. 197-237];

2. На думку представників когнітивної психології, категоріальне об'єднання стимулів виникає на основі близькості реакцій. Емпіричні дослідження показали, що в просторі уявлень 
про тварин, реконструйованому на базі оцінок подібності, «кішка» виявляється ближче до «собаки», ніж до «тигра», оскільки поведінково (функціонально) ознака «дикий - домашній» виявляється для реального носія мови більш істотною, ніж поняттєві підстави суворої біологічної класифікації видів [1, с. 176-184].

3. У межах діяльнісного підходу розробляється ідея функціонального значення. Один і той же предмет, наприклад, палиця, може бути для мавпи-антропоїда позитивною умовою, інструментом діяльності на тлі одного мотиву (дістати плід) і негативною умовою на тлі іншого мотиву (страху перед покаранням). Л. С. Виготський говорить про значення тільки в контексті дослідження мовленнєвого мислення. О. М. Леонтьєв пов'язує значення з виникненням мови і свідомості як знарядь виключно людської психіки [26, с. 20];

4. У психолінгвістиці два аспекти значення слова були розмежовані і протиставлені один одному: значення як об'єктивного психічного феномена і значення як суб'єктивного факту, що залежить від усвідомлення носієм мови свого мовлення [23, с. 13].

I. I. Матюшина, узагальнюючи історичні концепції значення і сенсу, виділяє «менталістський» та «лінгвоцентристський» підходи. На іiі думку, «менталісти» вбачають джерело сенсів у свідомості людини, а роботу мовлення розуміють як утілення, структуризацію, репрезентацію змісту свідомості в деяких знакових формах (Е. Гуссерль, Г. Фреге, В. фон Гумбольдт і О. О. Потебня); «лінгвоцентристи» вважають, що мова як ціле через свою внутрішню структуру породжує сенси відповідно до правил мови (представники Л. Вітгенштейн, Ф. де Соссюр). Еволюція цих підходів привела до формування комунікативної концепції (будь-який сенс є комунікативним у тому аспекті, що він народжується не тільки в підсистемах адресанта S1 і адресата S2, він народжується у процесі їх зіткнення, взаємодії [14, c. 40]). Комунікативна гіпотеза підтверджується сучасними нейрофізіологічними дослідженнями, згідно 3 результатами яких співрозмовники інтуїтивно та інтерактивно домовляються про значення деяких слів, таким чином, що ці слова в контексті розмови отримують конкретні значення, відмінні від словникових, тому стороння людина далеко не завжди може зрозуміти сенс бесіди [27, с. 118]. таблиці.

Результат узагальнення сучасних психологічних концепцій значення та сенсу подано у

Диференціація значення та сенсу в сучасній психології

\begin{tabular}{|c|c|c|c|}
\hline & Автор підходу & Значення - & Сенс- \\
\hline 1 & $\begin{array}{l}\text { Л. С.Виготський [19, } \\
\text { с. 193] }\end{array}$ & $\begin{array}{l}\text { властивість знаку, } \\
\text { результат віднесення } \\
\text { конкретного змісту } \\
\text { свідомості до певного } \\
\text { класу, групи, типу явищ }\end{array}$ & $\begin{array}{l}\text { те, що входить у значення } \\
\text { (результат значення), але не } \\
\text { закріплено за знаком; сенс ширший } \\
\text { від значення }\end{array}$ \\
\hline & $\begin{array}{l}\text { О. Р. Лурія [12, с. } \\
\text { 54] }\end{array}$ & $\begin{array}{l}\text { стійка система } \\
\text { узагальнень, що стоїть за } \\
\text { словом, однакова для } \\
\text { всіх людей, причому ця } \\
\text { система може мати різну } \\
\text { глибину, рівень } \\
\text { узагальнення, різну } \\
\text { широту охоплення } \\
\text { предметів, але вона } \\
\text { обов'язково зберігає } \\
\text { незмінне «ядро»- } \\
\text { певний набір зв'язків }\end{array}$ & $\begin{array}{l}\text { індивідуальне значення слова, } \\
\text { виділене з цієї об'єктивної системи } \\
\text { зв'язків; воно складається з тих } \\
\text { зв'язків, які мають відношення до } \\
\text { даного моменту і до даної ситуації. } \\
\text { Тому, якщо «значення» слова є } \\
\text { об'єктивним відображенням } \\
\text { системи зв'язків і відносин, то } \\
\text { «сенс» - це привнесення } \\
\text { суб'єктивних аспектів значення від- } \\
\text { повідно до даного моменту і } \\
\text { ситуації }\end{array}$ \\
\hline & Ю. А. Сорокін & сутність предмета, & інтерпретація цього значення на \\
\hline
\end{tabular}




\begin{tabular}{|c|c|c|}
\hline$[22$, c. 59$]$ & $\begin{array}{l}\text { співіднесена з деяким } \\
\text { знаком }\end{array}$ & $\begin{array}{l}\text { основі колективного та / або } \\
\text { особистого досвіду }\end{array}$ \\
\hline $\begin{array}{l}\text { Д. О. Леонтьєв } \\
{[10, \text { с. } 20]}\end{array}$ & $\begin{array}{l}\text { об'єктивні властивості і } \\
\text { зв'язки об'єктів і явищ, } \\
\text { загальне і соціальне }\end{array}$ & $\begin{array}{l}\text { відображення індивідуально } \\
\text { значущих властивостей, відношення } \\
\text { суб'єкта до цих об'єктів і явищ, не } \\
\text { заданий арriori, а створюваний на } \\
\text { кожному етапі; джерелом, що } \\
\text { приписує сенс речам, є свідомість, } \\
\text { актуальний впорядкований досвід }\end{array}$ \\
\hline $\begin{array}{l}\text { Г. Фреге } \\
{[10, \text { с. 10]. }}\end{array}$ & обмежене референтом & $\begin{array}{l}\text { абсолютний: текст може мати тільки } \\
\text { одне значення, але декілька сенсів, } \\
\text { або ж не мати значення (якщо в } \\
\text { реальності йому ніщо не } \\
\text { відповідає), але мати при цьому } \\
\text { сенс }\end{array}$ \\
\hline $\begin{array}{l}\text { А. І. Новіков [16, } \\
\text { с. } 143]\end{array}$ & $\begin{array}{l}\text { «проекція тексту на } \\
\text { свідомість» }\end{array}$ & $\begin{array}{l}\text { «проекція свідомості на текст»; } \\
\text { сенс базується певною мірою на } \\
\text { з'ясуванні «суті справи, } \\
\text { запрограмованої автором у задумі } \\
\text { тексту, що уявляє собою певний } \\
\text { код, який слід розшифрувати» }\end{array}$ \\
\hline $\begin{array}{l}\text { О. В. Бондарко, } \\
\text { Т. С. Сєрова [4; } 20 \text {, } \\
\text { с. } 235]\end{array}$ & $\begin{array}{l}€ \text { змістовною стороною } \\
\text { деякої одиниці певної } \\
\text { мови як елементу } \\
\text { системи мови }\end{array}$ & $\begin{array}{l}\text { явище мови, що має контекстну і } \\
\text { ситуативну обумовленість і } \\
\text { передається різними одиницями } \\
\text { цієї мови }\end{array}$ \\
\hline $\begin{array}{l}\text { M. O. Opan [17, } \\
\text { c. 231]. }\end{array}$ & $\begin{array}{l}\text { відображення істотних } \\
\text { характеристик об'єктів, } \\
\text { здебільшого когнітивний } \\
\text { компонент }\end{array}$ & $\begin{array}{l}\text { відношення між суб'єктом і } \\
\text { об'єктом, - здебільшого особистісне } \\
\text { утворення }\end{array}$ \\
\hline $\begin{array}{l}\text { Н. М. Нестерова } \\
{[15, \text { с. } 7-8]}\end{array}$ & $\begin{array}{l}\text { об'єктивне, стабільне, } \\
\text { задається } \\
\text { знаком / текстом }\end{array}$ & $\begin{array}{l}\text { суб'єктивний, мінливий, } \\
\text { нестабільний, завжди } \\
\text { вибудовується }\end{array}$ \\
\hline
\end{tabular}

В. М. Манакін стверджує, що лексичну пам'ять людини становлять саме найсуттєвіші семантичні ознаки; вони $є$ також основою і самих лексичних значень. Лексичні значення слів та ix компоненти у такому розумінні можна розглядати як опорні моделі для формування смислового змісту, який стовідсотково ніколи не буде збігатися у різних людей та соціумів. Значення слова відбиває усталені знання про предмети та лінгвальний спосіб їх вираження. Лінгвістичний словник перелічує значення лексичних одиниць, а не їхні смисли. Семантика слова, що фіксується у філологічних словниках («найближче значення», за О. О. Потебнею), $є$ вторинною, похідною відносно людських знань про світ» [13, с. 178].

Висновки. Отже, розуміння розглядаємо як складний процес, що починається від сприймання, частково охоплює мислення та пам'ять (на етапі раціональної інтерпретації) i завершується у свідомості (де відбувається емоційна інтерпретація й усвідомлення). В результаті розуміння у свідомості суб'єкта виникають певні організовані уявлення щодо тексту смисли, які згодом набувають вербальної форми, об'єктивуючись як вторинний текст (отриманий від реципієнта як реакція на прочитаний текст), у якому ці вторинні смисли репрезентовані. У такому тлумаченні розуміння його психологічним механізмом $є$ процес 
розкладання значень тексту на їх семантичні компоненти та утворення на цій основі власних вторинних смислів. Відповідно критерієм відбору прийнятних смислів може виступати контекст, що підтримує одні смисли та відкидає інші на основі спільності попереднього смислового змісту (Р. Краус, Н. В. Ігнатенко, В. В. Жовтянська, Г. В. Лосик та ін.), або ширше спільний досвід, що формує такий спільний контекст (О. О. Залевська, М. Якобоні). Суттєвими диференційними ознаками значення та смислу $\epsilon$ такі: смисл виникає при зіткненні пропонованого текстом значення з наявними у свідомості реципієнта смислами за потреби їх узгодження; значення - загальне, об’єктивне, закріплене за словом, смисл - індивідуальний, суб'єктивний, не закріплений, а лише асоційований, тому він, як правило, ширший від значення. Теза про те, що значення слів перелічені у словнику (В. М. Манакін має на увазі, певно, тлумачний словник), а смисли вочевидь формуються на основі компонентів значень, дає підстави шукати ці компоненти у словниках. Тобто семи, представлені у тлумачних словниках, можна розглядати як базу для формування смислів щодо зазначеного слова. А спільні семи слів, що становлять текст, утворюють текстуальні обмеження його розуміння. Отже, тлумачний словник можна використовувати для верифікації адекватності розуміння на основі зіставлення словникових сем та отриманих вторинних значень.

1. Henley, N. (1969). A psychological study of the semantics of animal terms. J. verb, learn. \& Verb, behavior, 8, 176-184.

2. Osgood, C. E. (1952). The nature and measurement of meaning. Psychol. Bulletin, 49, 197-237.

3. Агафонов, А. Ю. (2000). Человек как смысловая модель мира. Пролегомены к психологической теории смыслла. Самара: Изд. Дом «БАХРАХ-М».

4. Бондарко, А. В. (1978). Грамматическое значение и смысл. М.: «Наука».

5. Жовтянська, В. В. (2009). Діалектика смислу і значення. Проблеми загальної та педагогічної психології: зб. наук.пр. Ін-ту психології ім. Г. С. Костюка АПН Украӥни, 11 (6), 173-182.

6. Залевская, А. А. (1999). Введение в психолингвистику. М.: Российск. гос. ун-т.

7. Ігнатенко, Н. В. Психологічна характеристика тексту й проблеми його розуміння Взято 3 http://library.udpu.org.ua/library_files/psuh_pedagog_probl_silsk_shkolu/6/visnuk_19.pdf.

8. Краусс, Р. (1988). Познание и общение. М.: Наука.

9. Леонтьев, Д. А. (2003). Психология смысла: строение и динамика смысловой реальности. М.: Смысл.

10. Леонтьев, Д. А. (1996). Значение и личностный смысл: две стороны одной медали. Психологический журнал, 17 (5), 19-30.

11. Лосик, Г. В., Фридланд, А. Я., Лебедев, А. Н., Вартанов, А. В. (2013). Психология сознания человека и информационные технологи. Идеи О. К. Тихомирова и А. В. Брушлинского и фундаментальные проблемы психологии (к 80-летию со дня рождения). Материалы Всероссийской научной конференции (с иностранным участием). Москва, 30 мая - 1 июня 2013 г. М.: Московский государственный университет имени М. В. Ломоносова.

12. Лурия, А.Р. (1979). Язык и сознание. Хомской Е. Д. (Ред.). М.: МГУ.

13. Манакін, В. М. (2012). Смисл і значення слова в аспектах контрактивної лексикології і перекладу. Нова філологія. Збірник наукових пращь, 50, 177-180.

14. Матюшина, I. I. (2007). Комунікативна природа смислу. (Автореф. дис. на здобуття наук. ступеня канд. філос. наук). Південноукраїнський державний педагогічний університет ім. К.Д. Ушинського, Одеса.

15. Нестерова, Н. М. (2009). Психолингвистика текста, или есть ли смысл в тексте. Bonpocbl психолингвистики, 9, 213-219.

16. Новиков, А. И. (2007). Текст и его смысловые доминантыл. М.: «Азбуковник».

17. Орап, М. О. (2014). Психологічні основи організаиї̈ мовленнєвого досвіду особистості. (Дис. док. психол. наук). Ін-т психології ім. Г. С. Костюка, Київ.

18. Савелюк, Н.М. (2018). Психологія розуміння особистістю релігійного дискурсу. (Автореф. на здобуття наук. ступеня док. психол. наук). Київський національний університет імені Тараса Шевченка, Київ.

19. Семенуха, О.І.(2010).Психосемантика: тенденції та перспективи дослідження індивідуальної свідомості. Психологічні перспективи, Вип.15, 191-198.

20. Серова, Т.С. (2009). Осмысление, понимание и фиксация информации исходного текста как программы предметного содержания и смыслового развития вторичного текста письменного перевода. Bonpocbl психолингвистики, 9, 231-241.

21. Серый, А. В. (2002). Психологические механизмы функиионирования системы личностных смыслов. Кемерово: Кузбассвузиздат.

22. Сорокин, Ю. А. (1985). Психолингвистические аспекты изучения текста. М.: Наука. 
23. Уфимцева, А. А. (1986). Лексическое значение (Принцииь семиологического описания лексики). Ю. С. Степанов (Ред.). М.: Наука.

24. Харченко, Н. В. (2014). Розуміння як психологічний феномен. Психолінгвістика. Психолингвистика. Psycholinguistics, Вип. 15, 178-193.

25. Чепелєва, Н. В. (1992). Психологія читання навчальної та наукової літератури в системі професійної підготовки студентів. (Автореф. дис. д-ра психол. наук). КДПІ ім. М. П. Драгоманова, Київ.

26. Шмелев, А. Г. (1983). Концепция систем значений в экспериментальной психосемантике. Bonросы психологии, 4, 16-28.

27. Якобони, М. (2011). Отражаясь в людях: Почему мы понимаем друг друга; пер. с англ. Л. Мотылев. М. ООО «Юнайтед Пресс».

\section{REFERENCES}

1. Henley, N. (1969). A psychological study of the semantics of animal terms / N. Henley // J. verb, learn. \& Verb, behavior, 8, 176-184.

2. Osgood, C. E. (1952). The nature and measurement of meaning. Psychol. Bulletin, 49, 197-237.

3. Agafonov, A. Yu. (2000). Chelovek kak smyslovaya model' mira. Prolegomeny $k$ psikhologicheskoy teorii smysla [Man as a semantic model of the world. Prolegomena to the psychological theory of meaning]. Samara: Izd. Dom BAKHRAKH-M. (rus).

4. Bondarko, A. V. (1978). Grammaticheskoye znacheniye i smysl [Grammatical meaning and sense]. Moscow: Nauka. (rus).

5. Zhovtyanska, V. V. (2009). Dialektyka smyslu i znachennya [Dialectics of meaning and sense]. Problemy zahal'noyi ta pedahohichnoyi psykholohiyi: zbirnyk naukovykh prats' Instytutu psykholohiyi imeni H. S. Kostyuka APN Ukrayiny [Problems of general and pedagogical psychology: the collection of scientific works of the G.S. Kostyuk Institute of Psychology of the Academy of Pedagogical Sciences of Ukraine], 11 (6), 173-182. (ukr).

6. Zalevskaya, A. A. (1999). Vvedeniye v psikholingvistiku [Introduction to psycholinguistics]. Moscow: Rossiysk. gos. un-t. (rus).

7. Ígnatenko, N.V. Psikhologíchna kharakteristika tekstu y problemi yogo rozumínnya [Psychological characteristics of the text and problems of its understanding]. Library.udpu.org.ua. - Retrieved from http://library. udpu.org.ua /library_files/psuh_pedagog_probl_silsk_shkolu/6/visnuk_19.pdf

8. Krauss, R. (1988). Poznaniye i obshcheniye [Cognition and communication]. Moscow: Nauka. (rus).

9. Leontyev, D. A. (2003). Psikhologiya smysla: stroyeniye i dinamika smyslovoy real'nosti [Psychology of sense: the structure and dynamics of semantic reality]. Moscow: Smysl. (rus).

10. Leontyev, D.A. (1996). Znacheniye i lichnostnyy smysl: dve storony odnoy medali [Meaning and personal meaning: two sides of the same coin]. Psikhologicheskiy zhurnal. [Psychological Journal], 17 (5), 19-30. (rus).

11. Losik, G. V., Fridland A. YA., Lebedev A. N., Vartanov A. V. (2013). Psikhologiya soznaniya cheloveka i informatsionnyye tekhnologii [Psychology of Human Consciousness and Information Technologies]. Idei O.K. Tikhomirova $i$ A. V. Brushlinskogo i fundamental'nyye problemy psikhologii (k 80-letiyu so dnya rozhdeniya): Materialy Vserossiyskoy nauchnoy konferentsii (s inostrannym uchastiyem). Moskva, 30 maya - 1 iyunya $2013 \mathrm{~g}$. [Ideas by O. K. Tikhomirova and A. V. Brushlinsky and the fundamental problems of psychology (on the 80th anniversary of his birth): Materials of the All-Russian Scientific Conference (with foreign participation], 267-269. (rus).

12. Luriya, A. R. (1975). Osnovnyye problemy neyrolingvistiki [The main problems of neurolinguistics]. Moscow: Izd-vo Mosk. un-ta. (rus).

13. Manakin, V. M. (2012). Smysl i znachenya slova v aspektakh kontrastyvnoyi leksykolohiyi i perekladu [The sense and meaning of the word in the aspects of contrastive lexicology and translation]. Nova filolohiya. Zbirnyk naukovykh prats [ New Philology. Collection of scientific works], 50, 177-180. (ukr).

14. Matyushyna, I. I. (2007). Komunikatyvna pryroda smyslu [Communicative nature of sense]. (Avtoref. dys. na zdobuttya nauk. stupenya kand. filos. nauk) [Author's abstract for the degree of Cand. of Philosop.]. Pivdennoukrayinskyy derzhavnyy pedahohichnyy universytet im. K.D. Ushynskoho, Odesa. (ukr).

15. Nesterova, N. M. (2009). Psikholingvistika teksta, ili yest' li smysl v tekste? [Psycholinguistics of the text, or is there any sense in the text?]. Voprosy psikholingvistiki [ Questions of psycholinguistics], 9, 213-219. (rus).

16. Novikov, A. I. (2007). Tekst i yego smyslovyye dominanty [The text and its semantic dominants]. Moscow: Azbukovnik. (rus).

17. Orap, M. O. (2014). Psykholohichni osnovy orhanizatsiyi movlennyevoho dosvidu osobystosti [Psychological bases of organization of the individual speech experience]. (Dys. dok. psykhol. nauk) [Dissertation for the degree of Doc. of Psychol. Sciences]. In-t psykholohiyi im. H. S. Kostyuka, Kyiv. (ukr).

18. Savelyuk, N.M. (2018). Psykholohiya rozuminnya osobystistyu relihiynoho dyskursu [Psychology of understanding the personality of religious discourse]. (Avtoref. na zdobuttya nauk. stupenya dok. psykhol. nauk) [Author's abstract for the degree of Doc. of Psychol. Sciences]. Natsionalnyy pedahohichnyy universytet im. M.P. Drahomanova, Kyiv. (ukr). 
19. Semenukha, O. I. (2010). Psykhosemantyka: tendentsiyi ta perspektyvy doslidzhennya indyvidual'noyi svidomosti [Psychosemantics: Trends and Prospects for the Study of Individual Consciousness]. Psykholohichni perspektyvy. [Psychological Perspectives], 15, 191-198. (ukr).

20. Serova, T. S. (2009). Osmysleniye, ponimaniye i fiksatsiya informatsii iskhodnogo teksta kak programmy predmetnogo soderzhaniya i smyslovogo razvitiya vtorichnogo teksta pis'mennogo perevoda [Recognizing, understanding and recording information in the source text as a program of subject content and semantic development of the secondary text of a written translation]. Voprosy psikholingvistiki [Questions of psycholinguistics], 9, 231-241. (rus).

21. Seryy, A. V. (2002). Psikhologicheskiye mekhanizmy funktsionirovaniya sistemy lichnostnykh smyslov [Psychological mechanisms of functioning of the system of personal semantic].Kemerovo: Kuzbassvuzizdat. (rus).

22. Sorokin, Yu. A. (1985). Psikholingvisticheskiye aspekty izucheniya teksta [Psycholinguistic aspects of studying a text]. Moscow: Nauka. (rus).

23. Ufimtseva, A.A. (1986). Leksicheskoye znacheniye (Printsipy semiologicheskogo opisaniya leksiki) [The lexical meaning (Principles of the semiological description of vocabulary)]. Moscow: Nauka. (rus).

24. Kharchenko, N.V. (2014). Rozuminnya yak psykholohichnyy fenomen [Understanding as a psychological phenomenon]. Psykholinhvistyka. Psykholynhvystyka. Psycholinguistics, 15, 178-193. (ukr).

25. Chepelyeva, N.V. (1992). Psykholohiya chytannya navchal'noyi ta naukovoyi literatury $v$ systemi profesiynoyi pidhotovky studentiv [Psychology of Academic and Scientific Literature Reading in the System of Students' Professional Training]. (Avtoref. na zdobuttya nauk. stupenya dok. psykhol. nauk) [Author's abstract for the degree of Doc. of Psychol. Sciences]. Kyiv: KDPI im. M. P. Drahomanova. (ukr).

26. Shmelev, A.G. (1983). Kontseptsiya sistem znacheniy v eksperimental'noy psikhosemantike [The concept of meaning systems in experimental psychosemantics]. Voprosy psikhologii, 4, 16-28. (rus).

27. Yakoboni, M. (2011). Otrazhayas v lyudyakh: Pochemu my ponimayem drug druga [Reflecting in people: Why we understand each other]. Moscow: Yunayted Press. (rus).

\section{Nataliia Akimova \\ PSYCHOLOGICAL MECHANIZM OF TEXT UNDERSTANDING}

The article is devoted to the substantiation of the psychological mechanism of text understanding on the basis of a generalization of the scrupulous modern scientific works. It is noted that the question of the text understanding mechanism has not yet received an exhaustive answer. Often, hypothesis theory, the theory of community significance, the hypothesis of biological and functional similarity of attribution of meanings, the model of contextual semantic restriction of words, the hypothesis of the relevance of the context, the theory of mirror neurons, and the concept of conscious thought-making are used to explain the psychological mechanism of text understanding. Meanwhile, results of analysis and synthesis of scientific literature, elements of descriptive, correlative and conceptual analysis let propose that the psychological mechanism of text understanding is the interaction of meaning and sense. The scientific analysis of these concepts led to the distinction of their differential features and gave reason to reconcile the representational arguments in the following hypothesis: sense is certain organized ideas about the text, it appears in the mind as a result of text understanding and represents into the secondary text. The psychological mechanism of understanding, respectively, is the process of decomposition of the text meanings into their semantic components and the formation of secondary sense on this basis. A criterion for selecting acceptable sense can be the context that supports some sense and rejects others based on the generality of the prior semantic content (R. Kraus, N. V. Ihnatenko, V. V. Zhovtyans'ka, H. V. Losyk), or more widelya common experience, which forms such a common context $(O$. O.Zalevs 'ka, M. Yakaboni). The contact the text proposed meaning with sense that existing in the recipient minds for their agreement led to appear the new secondary sense of the of the meanings; meaning is general, objective, fixed by word, sense is individual, subjective, not fixed, but only associate, therefore, it is usually wider than meaning.

Keywords: understanding, text understanding, understanding mechanism, meaning, sense. 